\title{
Asian Insfastructure Investment Bank (AIIB) Sebagai Bentuk Hegemoni Baru Tiongkok
}

\section{Cindy Rezma Fanny, Dwi Nur Arifianti, Erlandi Daffa Augusta}

\author{
Program Studi Hubungan Internasional, Universitas Muhammadiyah Malang - Indonesia \\ Email: cindyrezmafanny@gmail.com \\ Diserahkan: 23 Maret 2019 | Diterima: 24 April 2019
}

\begin{abstract}
Since the rise of China as a 'great power' in the 1940s, China has continued to expand its economic power. His role which was felt to be insignificant in the world multilateral institutions or BrettonWoods institutions made China initiate a new multilateral institution which was considered to have a bureaucracy that was easier than the Bretton-Woods institution. In addition, the financial condition of the World Bank which is considered inadequate for the Asian infrastructure development needs and the failure of America to host China so that the American allies want to join the AIIB make China more convinced by its decision to establish AIIB. AIIB initiated by President Xi Jinping and announced its establishment in 2014. In 2015, 57 founding countries officially signed the Article of Agreement (AOA) as the basis for the formation of the AIIB. In this study, the researcher will explain the motivations behind the formation of the AIIB. This research explained through a quantitative descriptive method so that the researcher will explain the purpose of establishing AIIB in detail. As a result, by analyzing through the perspective of Dependency Theory, the dependence of third world countries on the AIIB would indirectly bring about hegemony from China.
\end{abstract}

Keywords: AIIB, Depedency Theory, Tiongkok, Interest, Hegemony.

\begin{abstract}
Abstrak
Sejak munculnya Tiongkok sebagai 'great power' tahun 1940-an, membuat Tiongkok terus melakukan perluasan kekuatan ekonomi. Perannya yang dirasa tidak signifikan di lembaga multilateral Bretton-Woods membuat Tiongkok berinisiatif untuk membentuk lembaga multilateral baru yang dinilai memiliki birokrasi yang lebih mudah dibandingkan rezim BrettonWoods. Selain itu, kondisi keuangan World Bank yang dianggap tidak mencukupi kebutuhan pengembangan infrastruktur kawasan Asia dan kegagalan Amerika memusuhi Tiongkok menyebabkan sekutu Amerika tetap ingin bergabung dengan Asian Infrastructure Investment Bank (AIIB). AIIB sendiri diinisiasi oleh Presiden Xi Jinping yang didirikan pada tahun 2014. Tahun 201557 negara pendiri resmi menandatangani Article of Agreement (AOA) sebagai landasan terbentuknya AIIB. Didalam penelitian akan dijelaskan tentang motivasi Cina dibalik pembentukan AIIB. Penelitian ini dijelaskan secara deskriptif yang disertai data-data kuantitatif dengan menganalisis melalui sudut pandang Dependency Theory yang mengindikasikan bahwa keberadaan AIIB secara tidak langsung menciptakan ketergantungan terhadap negara-negara dunia ketiga dan memunculkan hegemoni Tiongkok.
\end{abstract}

Kata Kunci: AIIB, Teori Depedensi, Kepentingan, Tiongkok, Hegemoni.

\section{PENDAHULUAN}

Saat ini Tiongkok telah cepat di mana negara ini menjadi salah mengalami perubahan yang sangat satu negara terkuat dan terkaya. 
Sebagai negara dengan jumlah penduduk terbanyak di dunia dengan total sekitar 1,3 miliar menjadikan Tongkok sebagai salah satu negara Asia yang menjadi sentral ekonomi dunia. Pertumbuhan dan perkembangan ekonomi yang sangat cepat diwarnai dengan modernisasi sejak tahun 1978 membuat Tiongkok beradap pada posisi yang semakin kuat dalam sistem dan tatanan internasional (Silfiana, 2018). Dengan pertumbuhan dan pembangunan ekonomi China yang cepat membuat banyak negaranegara di dunia saat ini mulai tertarik dengan poros baru kekuatan ekonomi global tersebut.

\section{Dalam}

perekonomian mempunyai dunia, menghadapi menentukan beberapa langkah dan tindakan dengan berpegang teguh pada kekuatan domestik sebagai nilai utama dalam membangun perekonomian nasional. Adapun strategi yang ditempuh oleh Tiongkok dikenal dengan istilah "Konsensus Beijing" (Beijing Consensus) yang dirumuskan atas tiga hal pokok. Pertama, pembangunan negara berlandaskan inovasi. Kedua, keberhasilan ekonomi tidak hanya dengan ukuran pertumbuhan Produk Domestik Bruto (GDP) per kapita, tetapi juga dengan kesinambungan (sustainability) dan tingkat mutunya. Ketiga, keteguhan diri (self- determination) bagi Tiongkok (Ramo, 2004). Dengan elemen-elemen fundamental yang mengandung prinsip-prinsip dasar tersebut membuat pemerintah Tiongkok menjalankan kegiatan perekonomian yang dijalankan atas dua kepentingan, yakni mendorong percepatan pertumbuhan ekonomi dan memberikan ruang terbatas bagi kebebasan politik demi stabilitas pemerintahan.

Atas dasar itu, pada 2 Oktober 2013, pemerintahan Tiongkok meresmikan lahirnya suatu lembaga keuangan internasional, yaitu Asian Infrastucture Investment Bank (AIIB). AIIB adalah sebuah bank pembangunan multilateral/Multilateral Development Bank (MDB) berbasis pengetahuan modern yang fokus terhadap pembangunan infrastruktur dan sektor produktif di kawasan Asia. Walaupun bank ini diberi nama bank Asia, namun setiap negara di seluruh dunia dapat terlibat sebagai anggota di dalamnya (Weiss, 2017). Saat ini jumlah anggota telah mencapai 93 negara di dunia (AIIB, 2016). Keberadaan AIIB merupakan salah satu pelengkap dalam pembiayaan pembangunan infrastruktur negara anggota di berbagai kawasan.

Meskipun demikian, beberapa kalangan menyebut bahwa AIIB merupakan sebuah bentuk institusi keuangan internasional baru yang 
mengandung unsur kepentingan geopolitik dan geoekonomi Tiongkok serta merupakan alat yang digunakan untuk menanamkan hegemoninya terhadap negara-negara anggota. AIIB juga dianggap sebagai bentuk perlawanan terhadap sistem Bretton Woods dan institusi keuangan internasional yang telah berdiri sebelumnya. AIIB juga dinilai sebagai pesaing dari IMF dan World Bank karena dianggap konservatif dan didominasi oleh Amerika Serikat, Eropa, dan Jepang. Pemerintah Tiongkok mengatakan bahwa AIIB dibentuk sebagai sebuah ekspresi sikap frustrasi pemerintah Tiongkok terhadap lambannya reformasi dan tata kelola ekonomi global (Debora, 2017). Oleh karena itu, dalam penelitian ini akan dijelaskan tentang motivasi yang melatarbelakangi Tiongkok dalam pembentukan AIIB. Apakah AIIB benar hanya sebagai alat Tiongkok untuk menghegemoni negara dunia ketiga terutama di Asia?

\section{METODE PENELITIAN}

Dalam penelitian ini dignakan metode deskriptif kualitatif. Metode deskriptif menurut Mochtar Mas'oed adalah upaya untuk menjawab pertanyaan siapa, apa, di mana, bagaimana, kapan atau berapa (Mas'oed, 1990). Beliau juga menambahkan bahwa deskripsi merupakan umumnya dilakukan sebelum eksplanasi dan prediksi. Metode penelitian kualitatif menurut Wahidmurni adalah suatu cara yang digunakan untuk menjawab masalah penelitian yang berkaitan dengan data berupa narasi yang bersumber dari aktivitas wawancara, pengamatan, pengalian dokumen (Wahidmurni, 2017). Metode penelitian deskriptif kualitatif merupakan teknik menjelaskan masalah penelitian dengan menjawab pertanyaan yang berupa apa, bagaimana, siapa atau berapa yang datanya berupa narasi atau angka. Teknik mengumpulkan data yang digunakan dalam penelitian ini adalah archival and document based research dan internet based. Archival and document based research adalah jenis pengumpulan data yang meneliti berbagai macam dokumen yang berguna untuk bahan analisis (Samuel, 2016). Sedangkan internet based merupakan teknik pengumpulan data yang didapatkan melalui internet.

\section{KERANGKA TEORI}

Dalam

menganalisis permasalahan dalam penelitian ini digunakan dependency theory. Menurut Dos Santos dependency adalah struktur ekonomi dunia yang menguntungkan beberapa negara dan merugikan negara lain. Selanjutnya, Santos menyatakan bahwa ketergantungan adalah sebuah situasi di mana kelompok negara 
tertentu sangat dipengaruhi oleh ekspansi ekonomi negara lain (Santos dikutip Ferraro, 1996). Setidaknya terdapat tiga definisi umum yang diungkapkan oleh ahli teori depedensi. Pertama, ketergantungan mencirikan sistem internasional yang terdiri dari dua buah negara yang digambarkan dalam relasi antara negara dominan (umumnya negara maju) dan negara pinggiran (umumnya negara berkembang). Kedua, kekuatan tunggal eksternal adalah penting bagi kegiatan ekonomi dependent states. Ketiga, definisi ketergantungan mencirikan adanya interaksi antara negara dominan dan dependent states yang dapat memperkuat tetapi juga sekaligus mencerminkan pola yang tidak setara (Ferraro, 1996). Teori depedensi dalam penelitian ini akan digunakan untuk menjelaskan bagaimana bentuk hegemoni Tiongkok dan ketergantungan negaranegara dunia yang berada di kawasan Asia.

\section{HASIL DAN PEMBAHASAN}

Hasil dari penelitian ini menunjukkan bahwa bantuan investasi oleh AIIB yang dipelopori oleh Tiongkok dapat menyebabkan ketergantungan negara-negara dunia ketiga. Hasilnya, ketergantungan negara dunia ketiga tersebut dapat menjadi bentuk hegemoni baru dari Tiongkok.

\section{Sejarah AIIB}

AIIB adalah institusi pembangunan infrastruktur yang bersifat multilateral dengan misi meningkatkan kondisi sosial dan ekonomi di Asia (AIIIB, t.t) yang dibentuk pada tahun 2010 dan diumumkan oleh Presiden Xi Jinping pada Oktober 2013 saat perjalanannya ke Asia Tenggara (Insani \& Mardhiyah, 2017). Pada tanggal 24 Oktober 2014, 21 negara menandatangani nota kesepahaman pendirian AIIB di Beijeing (AIIB, t.t). Selanjutnya pada tanggal 29 Juni 2015, 57 negara prospective founding members menandatangani Article of Agreement (AOA) di Beijing (AIIB, t.t). Prospective founding members adalah nama yang diberikan kepada 57 negara pendiri AIIB yang dapat dilihat pada gambar sebagai berikut:

Gambar 1. Persebaran negara-negara pendiri AIIB

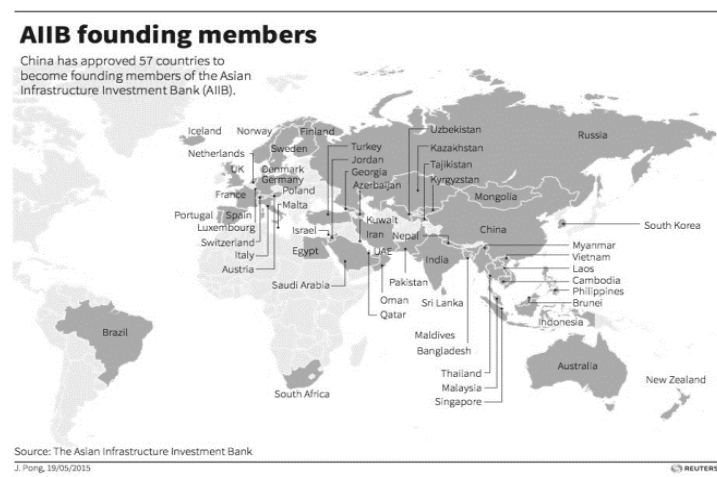

Sumber: http://www.businessworld.in/article/57Countries-Join-As-Founding-Members-Of-AIIB/1604-2015-80462/

Pada pertemuan ke 6 AIIB di Beijing yang diselenggarakan tanggal 
24 Agustus 2015, Jin Liquin terpilih sebagai Presiden AIIB melalui konsensus 57 negara (AIIB, t.t). Saat ini anggota AIIB berjumlah 93 negara yang tersebar diseluruh dunia. Walaupun AIIB adalah Bank Asia, namun anggotanya tidak hanya terdiri dari negara yang berada di kawasan yang sama, tetapi juga dari kawasan yang lain.

\section{Motivasi Tiongkok Mendirikan AIIB}

Di dalam Article of Agreement (AOA) dituliskan bahwa tujuan Asian Infrastructure Investment Bank meliputi dua hal. Pertama, mendorong investasi ekonomi yang bekelanjutan, meningkatkan kekayaan dan konektivitas infrastruktur di Asia. Kedua, mempromosikan kerjasama dan kemitraan regional dengan lembaga pembangunan multilateral lainnya (AIIB, 2016).

Sementara, fungsi AIIB sebagaimana yang tertuang dalam dalam Article of Agreement (AOA) meliputi empat hal. Pertama, mempromosikan investasi modal swasta untuk tujuan pengembangan infrastruktur dan sektor-sektor produktif. Kedua, memanfaatkan sumber daya yang tersedia untuk membiayai pembangunan di wilayah tersebut, termasuk proyek dan program yang akan berkontribusi bagi pertumbuhan ekonomi bagi anggota yang kurang berkembang. Ketiga, untuk mendorong investasi swasta dalam proyek pembangunan ekonomi kawasan serta untuk menopang permodalan pihak swasa. Keempat, melaksanakan kegiatan dan layanan lain yang mungkin mendukung fungsifungsi tersebut (AIIB, 2016).

Walaupun berdirinya AIIB ini ditandatangani oleh 57 negara pendiri. Namun, sebagai negara pendiri, Tiongkok memiliki motivasi tersendiri untuk membentuk AIIB. Terdapat beberapa alasan pendirian AIIB oleh Tiongkok. Pertama, sebagai kekuatan ekonomi terbesar kedua di dunia, Tiongkok hanya memiliki peran yang kecil di lembaga moneter dunia yaitu World Bank dan IMF (Chow, 2016). Kondisi ekonominya yang terus meningkat hingga menjadi posisi kedua setelah Amerika Serikat, namun posisi yang mereka dapatkan tidak signifikan di dalam sistem ekonomi dunia (Raharyo, 2013). Oleh karena itu, kehadiran AIIB dipandang sebagai upaya Tiongkok untuk meningkatkan peran penting dalam sistem ekonomi dunia. Motivasi kedua, mendorong perkembangan infrastruktur di Asia sehingga dapat mempercepat laju pertumbuhan ekonomi (Raharyo, 2013). Sebagaimana yang telah tertulis di dalam Article of Agreement (AOA) AIIB yang mengatakan bahwa:

"Acknowledging the significance of infrastructure development in expanding 
regional connectivity and improving regional integration, thereby promoting economic growth and sustaining social development for the people in Asia, and contributing to global economic dynamism (AIIB, 2016)."

Dari isi Article of Agreement (AOA) tersebut dapat diketahui bahwa AIIB membantu negara-negara di Asia untuk saling meningkatkan konektifitas regional sehingga pertumbuhan ekonomi dan pembangunan sosial akan semakin meningkat serta meningkatkan partisipasi dalam ekonomi global. Ketiga, kebutuhan pembangunan insfrastruktur yang semakin meningkat di Asia menambah keyakinan Tiongkok untuk mendirikan AIIB ditengah kekurangan dana World Bank (Chow, 2016). Pada tahun 2013 Asian Development Bank memperkirakan Asia membutuhkan dana sebesar $\$ 8$ triliun pertahun selama sepuluh tahun kedepan (Raharyo, 2013). Tahun 2017 Asian Development Bank (ADB) mengatakan bahwa kebutuhan infrastruktur di negara-negara berkembang di Asia dan Pasifik akan melebihi $\$ 22,6$ triliun hingga tahun 2030 atau sekitar $\$ 1,5$ triliun pertahun dan jika negara-negara tersebut ingin mempertahankan pertumbuhan diperkirakan akan naik hingga $\$ 26$ triliun atau $\$ 1,7$ triliun pertahun (ADB, 2017). Namun World Bank hanya memiliki dana sebesar
$\$ 252$ miliar, sangat jauh dari jumlah dana yang ditargetkan (Chow, 2016).

Motivasi keempat adalah respon terhadap dominasi ekonomi Amerika Serikat di Asia (Raharyo, 2013). AIIB dan program One Belt One Road yang diinisiasikan Tiongkok merupakan usaha meningkatkan posisi Tiongkok untuk menyeimbangkan kekuatan Amerika Serikat (Raharyo, 2013). Pemerintah Tiongkok tampak mencurigai bahwa Amerika Serikat akan menahan, mengisolasi, mengurangi, menyabotase kepemimpinan, dan memecah Tiongkok secara internal (Åberg, 2016). Kelima, usaha Amerika yang gagal dalam menekan Tingkok, membuat Tiongkok semakin yakin untuk mendirikan AIIB dengan keanggotaan yang luas (Chow, 2016). Sekutu Amerika Serikat tidak hanya memberikan kekuatan yang lebih terhadap Tiongkok di IMF, tetapi juga menolak ajakan Amerika Serikat untuk tidak bergabung dan menjauhi AIIB. Keenam, Tiongkok menggunakan AIIB sebagai alat untuk mencapai kepentingan nasionalnya dengan pendekatan terkenal dari Deng Xiaoping mengenai kebijakan luar negeri yaitu 'Taoguang Yanghui' yang berarti tetaplah rendah diri dalam menggapai sesuatu (Bob et.al., 2015). Namun, beberapa tahun terakhir pendekatan yang dikemukakan oleh Deng Xiaoping tidak lagi digunakan 
dan digantikan dengan postur yang tegas dan lebih percaya diri. Beberapa kepentingan Tiongkok yang ingin dicapai melalui AIIB antara lain: (i) stabilitas politik, (ii) keamanan yang berdaulat, integritas wilayah dan penyatuan nasional, (iii) ekonomi yang berkelanjutan dan pengembangan sosial (Bob et al., 2015).

Ketujuh, AIIB dapat digunakan sebagai alat mempromosikan strategi one belt one road Tiongkok (Bob et al., 2015). One belt one road sendiri adalah pembangunan Jalur Sutra baru yang menghubungkan Asia Tengah, Timur Tengah, dan Eropa serta Asia Tenggara dan Afrika melalui Samudera Hindia untuk melancarkan jalur ekonomi dan perdagangan antar negara (Bob et al., 2015). Kedelapan, untuk menyebarluaskan arus permodalan yang bersumber dari Tiongkok (Bob et al., 2015). Kesembilan, mendemokratisasikan tatanan ekonomi internasional (Bob et al., 2015).

Tiongkok menganggap lembaga multilateral dunia saat ini tidak adil dan merugikan negaranya dan negara lain. Motivasi-motivasi tersebut membuat Tiongkok begitu yakin bahwa untuk mendirikan lembaga multilateral seperti AIIB. Selain memberikan persyaratan yang mudah, dikatakan pula bunga pinjaman yang diberikan oleh AIIB jauh lebih kecil dibandingkan bank multilateral dunia lainnya.

\section{Strategi Finansial AIIB}

AIIB memiliki tiga landasan strategi yaitu, lean, clean, and green. Lean berarti tim manajemen yang efisien dan staf yang terampil. Clean berarti organisasi yang etis dan tidak ada toleransi terhadap korupsi. Green berarti lembaga yang dibangun atas dasar menghormati lingkungan (Bob et al., 2015).

Secara umum, sistem keuangan yang terdapat di AIIB tidak berbeda dengan sistem keuangan dari Multinational Development Bank lainnya. Seperti halnya MDB lain, modal AIIB bersumber dari hibah dan negara anggota (Bob et al., 2015). Dalam upaya mengumpulkan dana yang digunakan untuk memberikan pinjaman non-lunak kepada negara anggota yang sedang berkembang, MDB menerbitkan obligasi di pasar modal internasional sesuai dengan basis modalnya (Bob et al., 2015).

Gambar 2. Sistem keuangan MDB.

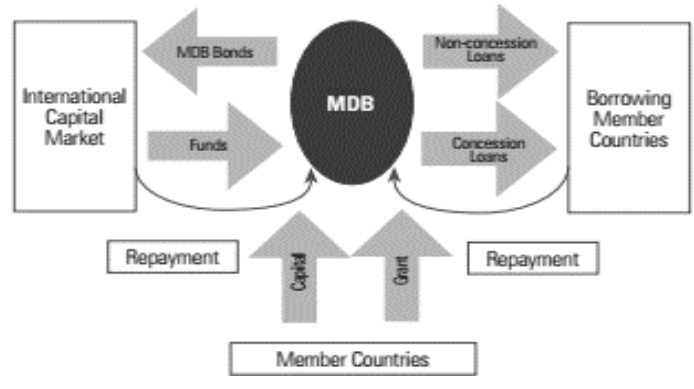

Sumber: Bob et al., Asian Infrastructure Investment Bank: China as Responsible Stakeholder. 
Terdapat beberapa perbedaan antara AIIB dengan MDB yang telah ada sebelumnya. Pertama, AIIB memiliki keanggotaan dan langganan modal yang relatif lebih besar. Kedua, pemegang saham utama berasal dari berasal dari Asia yang mewakili 70\% lebih modal. Ketiga, AIIB tidak memiliki dewan direksi seperti yang terdapat pada MDB lain yang memiliki struktur pemerintahan yang kuat. Keempat, modal diambil dari langganan modal sebesar 20\% yang mana lebih besar dari MDB lain, kecuali EBRD dan CAF. Kelima, Fokus utama yang berbeda dengan MDB lain, dimana MDB lain lebih berfokus pada kemiskinan, reduksi, pembangunan berkelanjutan dan pembangunan sosial. Sementara AIIB lebih berfokus pada investasi infrastruktur dan konektivitas (Bob et al., 2015). Berikut tabel yang menunjukkan perbedaan AIIB dengan MDB lain:

Tabel 1: Perbedaan MDB Utama, IMF dan AIIB

\begin{tabular}{|c|c|c|c|c|c|c|c|c|}
\hline & IMF & $\begin{array}{l}\text { World } \\
\text { Bank }\end{array}$ & EBRD & AIDB & ADB & IDB & CAFF & AIIB \\
\hline Established & 1944 & 1944 & 1991 & 1964 & 1966 & 1959 & 1968 & $\begin{array}{c}2015 \\
\text { (Planne } \\
\text { d) }\end{array}$ \\
\hline $\begin{array}{l}\text { Headquarte } \\
\text { rs }\end{array}$ & $\begin{array}{c}\text { Washingt } \\
\text { on DC, } \\
\text { US }\end{array}$ & $\begin{array}{c}\text { Washingt } \\
\text { on DC, } \\
\text { US }\end{array}$ & $\begin{array}{l}\text { London, } \\
\text { UK }\end{array}$ & $\begin{array}{c}\text { Abidjan, } \\
\text { Ivory } \\
\text { Coast }\end{array}$ & $\begin{array}{l}\text { Manila, } \\
\text { Philippin } \\
\text { es }\end{array}$ & $\begin{array}{l}\text { Washingt } \\
\text { on DC, } \\
\text { US }\end{array}$ & $\begin{array}{c}\text { Caracas, } \\
\text { Venezu } \\
\text { ela }\end{array}$ & $\begin{array}{c}\text { Beijing, } \\
\text { China }\end{array}$ \\
\hline Head & $\begin{array}{c}\text { European } \\
\text { (Christine } \\
\text { Lagarde) }\end{array}$ & $\begin{array}{c}\text { American } \\
\text { (Jim Yong } \\
\text { Kim) }\end{array}$ & $\begin{array}{c}\text { European } \\
\text { (Suma } \\
\text { Chakrabart } \\
\text { i) }\end{array}$ & $\begin{array}{c}\text { African } \\
\text { (Akinwu } \\
\text { mi } \\
\text { Adesina) }\end{array}$ & $\begin{array}{c}\text { Japanese } \\
\text { (Takehik } \\
\text { o } \\
\text { Nakao) }\end{array}$ & $\begin{array}{c}\text { South } \\
\text { American } \\
\text { (Luis } \\
\text { Alberto } \\
\text { Moreno) }\end{array}$ & $\begin{array}{c}\text { South } \\
\text { America } \\
\mathrm{n} \\
\text { (Enriqu } \\
\text { e Garcia }\end{array}$ & $\begin{array}{l}\text { Chinese } \\
\text { (Jin } \\
\text { Liquin, } \\
\text { expecte } \\
\text { d) }\end{array}$ \\
\hline $\begin{array}{l}\text { Member } \\
\text { Countries }\end{array}$ & 188 & 188 & $\begin{array}{c}64 \text { (Plus } \\
\text { EU\&EIB) }\end{array}$ & 80 & 67 & 48 & $\begin{array}{c}18 \text { (Plus } \\
14 \\
\text { private } \\
\text { banks) }\end{array}$ & $\begin{array}{c}50 \\
\text { June } \\
2015 \text { ) }\end{array}$ \\
\hline $\begin{array}{l}\text { Capital } \\
\text { Subscriptio } \\
\text { ns }\end{array}$ & $\begin{array}{c}\$ 368 \\
\text { billion }\end{array}$ & $\begin{array}{c}\$ 283 \\
\text { billion }\end{array}$ & $\begin{array}{c}\$ 39.4 \\
\text { billion } \\
(€ 29.7 \\
\text { billion })\end{array}$ & $\begin{array}{l}\$ 80.8 \\
\text { billion }\end{array}$ & $\begin{array}{l}\$ 163.5 \\
\text { billion }\end{array}$ & $\begin{array}{l}\$ 144.3 \\
\text { billion }\end{array}$ & $\begin{array}{c}\$ 7.8 \\
\text { billion }\end{array}$ & $\begin{array}{l}\$ 100 \\
\text { billion }\end{array}$ \\
\hline $\begin{array}{l}\text { Paid-in } \\
\text { capital ratio }\end{array}$ & - & - & $20.9 \%$ & $4.9 \%$ & $5.0 \%$ & $3.7 \%$ & $39.4 \%$ & $20.0 \%$ \\
\hline $\begin{array}{l}\text { Group } \\
\text { institutions }\end{array}$ & - & $\begin{array}{l}\text { IBRD, } \\
\text { IDA, IFC, } \\
\text { MIGA }\end{array}$ & - & $\begin{array}{l}\text { OCR, } \\
\text { AfDF, } \\
\text { NTF }\end{array}$ & $\begin{array}{l}\text { OCR, } \\
\text { ADF }\end{array}$ & IIC, MIF & & - \\
\hline $\begin{array}{l}\text { Major } \\
\text { Shareholder } \\
\text { s }\end{array}$ & $\begin{array}{c}\text { US, } \\
\text { Japan, } \\
\text { Germany, } \\
\text { UK \& } \\
\text { France, } \\
\text { China }\end{array}$ & $\begin{array}{l}\text { US, Japan, } \\
\text { China, } \\
\text { Germany, } \\
\text { France \& } \\
\text { UK }\end{array}$ & $\begin{array}{c}\text { US, } \\
\text { France, } \\
\text { Germany, } \\
\text { Italy, Japan } \\
\text { \& UK }\end{array}$ & $\begin{array}{c}\text { Nigeria, } \\
\text { US, } \\
\text { Japan, } \\
\text { Egypt, } \\
\text { South } \\
\text { Africa }\end{array}$ & $\begin{array}{l}\text { Japan, } \\
\text { US, } \\
\text { China, } \\
\text { India, } \\
\text { Australia }\end{array}$ & $\begin{array}{c}\text { US, } \\
\text { Argentin } \\
\text { a \& } \\
\text { Brazil, } \\
\text { Mexico, } \\
\text { Japan }\end{array}$ & $\begin{array}{c}\text { Peru, } \\
\text { Venezu } \\
\text { ela, } \\
\text { Colomb } \\
\text { ia, } \\
\text { Argenti } \\
\text { na, } \\
\text { Brazil }\end{array}$ & $\begin{array}{c}\text { China, } \\
\text { India, } \\
\text { Russia, } \\
\text { Germa } \\
\text { ny, } \\
\text { Korea }\end{array}$ \\
\hline
\end{tabular}




\begin{tabular}{|c|c|c|c|c|c|c|c|c|}
\hline $\begin{array}{l}\text { Developing } \\
\text { Country } \\
\text { voting } \\
\text { shares }\end{array}$ & $\begin{array}{l}\text { Developi } \\
\text { ng and } \\
\text { emerging } \\
\text { countries } \\
: 42.1 \%\end{array}$ & $\begin{array}{l}\text { Developin } \\
\mathrm{g} \text { and } \\
\text { emerging } \\
\text { countries : } \\
42.1 \%\end{array}$ & $\begin{array}{c}\text { Transition } \\
\text { economies } \\
: 13.8 \%\end{array}$ & $\begin{array}{l}\text { Regional } \\
: 59.5 \%\end{array}$ & $\begin{array}{c}\text { Regional } \\
: 65,1 \% \\
\text { (DMCs: } \\
46.8 \% \text { ) }\end{array}$ & $\begin{array}{c}\text { Regional } \\
: \\
50.015 \%\end{array}$ & $\begin{array}{c}\text { Regiona } \\
1: \\
95.5 \%\end{array}$ & $\begin{array}{c}\text { Regiona } \\
1: 75 \%\end{array}$ \\
\hline $\begin{array}{l}\text { Key } \\
\text { Decision }\end{array}$ & $\begin{array}{c}85 \% \\
\text { majority }\end{array}$ & $\begin{array}{c}80 \% \\
\text { majority }\end{array}$ & $\begin{array}{c}80 \% \\
\text { majority }\end{array}$ & $\begin{array}{c}70 \% \\
\text { majority }\end{array}$ & $\begin{array}{c}75 \% \\
\text { majority }\end{array}$ & $\begin{array}{c}75 \% \\
\text { majority }\end{array}$ & $\begin{array}{c}80 \% \\
\text { majority }\end{array}$ & $\begin{array}{c}75 \% \\
\text { majorit } \\
y\end{array}$ \\
\hline $\begin{array}{l}\text { Board of } \\
\text { Directors }\end{array}$ & Resident & Resident & Resident & Resident & Resident & Resident & $\begin{array}{l}\text { Non- } \\
\text { Residen } \\
\text { t }\end{array}$ & $\begin{array}{l}\text { Non- } \\
\text { Residen } \\
\mathrm{t}\end{array}$ \\
\hline Major Task & $\begin{array}{l}\text { Macro- } \\
\text { economic } \\
\text { stability, } \\
\text { response } \\
\text { to } \\
\text { financial } \\
\text { crisist }\end{array}$ & $\begin{array}{l}\text { Economic } \\
\text { developm } \\
\text { ent, } \\
\text { poverty } \\
\text { reduction, } \\
\text { and policy } \\
\text { advice }\end{array}$ & $\begin{array}{l}\text { Developm } \\
\text { ent of } \\
\text { open and } \\
\text { sustainable } \\
\text { market } \\
\text { economies } \\
\text { committed } \\
\text { to, and } \\
\text { applying, } \\
\text { democratic } \\
\text { principles }\end{array}$ & $\begin{array}{l}\text { Sustaina } \\
\text { ble } \\
\text { economi } \\
\text { c growth } \\
\text { and } \\
\text { reducing } \\
\text { poverty }\end{array}$ & $\begin{array}{l}\text { Econom } \\
\text { ic } \\
\text { develop } \\
\text { ment, } \\
\text { poverty } \\
\text { reductio } \\
\text { n, and } \\
\text { policy } \\
\text { advice }\end{array}$ & $\begin{array}{c}\text { Economi } \\
\mathrm{c} \text { and } \\
\text { social } \\
\text { develop } \\
\text { ment and } \\
\text { regional } \\
\text { integratio } \\
\mathrm{n}\end{array}$ & $\begin{array}{l}\text { Sustaina } \\
\text { ble } \\
\text { develop } \\
\text { ment } \\
\text { and } \\
\text { regional } \\
\text { integrati } \\
\text { on }\end{array}$ & $\begin{array}{l}\text { Infrastr } \\
\text { ucture } \\
\text { develop } \\
\text { ment } \\
\text { and } \\
\text { connect } \\
\text { ivity in } \\
\text { Asia }\end{array}$ \\
\hline
\end{tabular}

Sumber: Bob et al. (2015) Asian Infrastructure Investment Bank: China as Responsible Stakeholder.

Seperti yang terlihat pada tabel di atas, modal awal AIIB yaitu sebesar $\$ 100$ miliar. Dimana modal tersebut akan dibagi satu juta sehingga setiap saham akan bernilai sebesar $\$ 100.000$ yang tersedia untuk anggota (AIIB, 2016). Modal awal tersebut akan dibagi menjadi paid-in shares dan callable shares, dimana paid-in shares bernilai $\$ 20$ miliar dan callable shares bernilai $\$ 80$ miliar (Asian Infrastructure Investment Bank, 2016). Modal awal tersebut akan digunakan untuk membiayai proyek pembangunan di negara anggota. Sebagaimana yang tertuang dalam Article of Agreement (AOA) bahwa Bank diizinkan untuk menyediakan pembiayaan dalam berbagai cara seperti memberikan pinjaman, investasi dalam modal perusahaan, menjamin sebagai obligor primer atau sekunder dalam pinjaman sebagian atau seluruhnya (AIIB, t.t). Dalam melakukan pembiayaan, AIIB memiliki syarat khusus yang harus dipenuhi yaitu, (1) persyaratan keuangan (suku bunga, biaya lain, jadwal pembayaran pokok) akan diatur oleh Bank sesuai pembiayaan yang bersangkutan dan resiko bagi Bank, (2) Bank wajib memasukkan syarat dan ketentuan untuk pinjaman atau jaminan dalam kontraknya, (3) jika penerima pinjaman atau penerima jaminan bukan berasal dari negara anggota maka Bank memiliki kebijaksanaan untuk mengharuskan anggota di wilayah yang proyeknya harus dilaksanakan menjamin pembayaran pokok dan pembayaran bunga dan biaya lainnya atas pinjaman sesuai dengan ketentuan, (4) jumlah investasi ekuitas tidak boleh melebihi dari modal ekuitas entitas tersebut, dan 
(5) Bank dapat menyediakan pembiayaan sesuai dengan mata uang negara terkait (Policy et al., 2017).

Dalam pembiayaan kegiatan persiapan suatu proyek, Bank dapat memberikan uang muka dengan jumlah pokok agregat maksimum 10\% jumlah perkiraan total pembiayaan proyek dan setara \$10 juta (Policy et al., 2017). Untuk pendanaan yang didukung oleh negara, Bank memiliki ketentuan antara lain: (1) mata uang pembayaran menggunakan Dolar Amerika Serikat;
(2) harga pinjaman yang terdiri dari suku bunga, biaya front-end dan biaya komitmen. Bunga yang dibayarkan dihitung berdasarkan jumlah pinjaman yang telah dicairkan dan belum dilunasi. Referensi kurs yang digunakan adalah LIBOR dan diatur ulang setiap tahun pada tanggal pembayaran bunga dan sifat spread tetap dan berlaku satu hari sebelum tanggal penandatanganan perjanjian sebagaimana yang tergambar pada tabel sebagai berikut:

Tabel 2. Biaya dan Penyebaran Pinjaman Untuk Pinjaman yang didukung negara

\begin{tabular}{|c|c|c|c|}
\hline Fee/ Spread & Rate & Charged On & One Time/Recurring \\
\hline Front-end Fee & $0.25 \%$ & Loan principal & One-Time \\
\hline Commitment Fee & $0.25 \%$ & $\begin{array}{l}\text { Undisbursed loan } \\
\text { balance }\end{array}$ & Recurring \\
\hline Leanding Spread & $\begin{array}{c}0.75 \% \text { to } \\
1.40 \%\end{array}$ & $\begin{array}{l}\text { Disbursed and } \\
\text { outstanding loan } \\
\text { balances }\end{array}$ & Recurring \\
\hline
\end{tabular}

Tabel 3. Komponen penyebaran pinjaman dan penyebaran pinjaman keseluruhan

\begin{tabular}{|c|c|c|c|c|c|c|}
\hline $\begin{array}{l}\text { Average } \\
\text { Maturity }\end{array}$ & $\begin{array}{l}\text { Up to } 8 \\
\text { years }\end{array}$ & $\begin{array}{c}\text { Greater } \\
\text { than } 8 \\
\text { through } 10 \\
\text { years }\end{array}$ & $\begin{array}{l}\text { Greater } \\
\text { than } 10 \\
\text { through } \\
12 \text { years }\end{array}$ & $\begin{array}{l}\text { Greater } \\
\text { than } 12 \\
\text { through } \\
15 \text { years }\end{array}$ & $\begin{array}{l}\text { Greater } \\
\text { than } 15 \\
\text { through } \\
18 \text { years }\end{array}$ & $\begin{array}{l}\text { Greater } \\
\text { than } 18 \\
\text { through } \\
20 \text { years }\end{array}$ \\
\hline $\begin{array}{l}\text { Contractual } \\
\text { Lending Spread }\end{array}$ & $0.50 \%$ & $0.50 \%$ & $0.50 \%$ & $0.50 \%$ & $0.50 \%$ & $0.50 \%$ \\
\hline $\begin{array}{l}\text { Maturity } \\
\text { Premium }\end{array}$ & $0 \%$ & $10 \%$ & $20 \%$ & $30 \%$ & $40 \%$ & $0.50 \%$ \\
\hline Risk Premium & $10 \%$ & $10 \%$ & $10 \%$ & $10 \%$ & $15 \%$ & $15 \%$ \\
\hline $\begin{array}{l}\text { Projected } \\
\text { Funding Spread } \\
\text { to LIBOR }\end{array}$ & $15 \%$ & $20 \%$ & $20 \%$ & $25 \%$ & $25 \%$ & $25 \%$ \\
\hline $\begin{array}{l}\text { Lending } \\
\text { Spread }\end{array}$ & $0.75 \%$ & $0.90 \%$ & $1.00 \%$ & $1.15 \%$ & $1.30 \%$ & $1.40 \%$ \\
\hline
\end{tabular}

Sumber: AIIB, Sovereign-Backed Loan and Guarantee Pricing

Biaya front-end dibebankan satu kali pada peminjaman dan dapat dibayar tidak lebih dari 60 hari setelah tanggal efektif. Biaya komitmen dibayarkan setiap enam bulan dibebankan pada tanggal pinjaman belum dicairkan dan 
akan bertambah setelah 60 hari pinjaman ditandatangani; (3) dewan menentukan harga untuk pinjaman dari waktu ke

waktu; (4) Bank menentukan jatuh tempo terakhir yang tunduk pada matury limit rata-rata hingga 20 tahun dan batas akhir jatuh tempo 35 tahun; (5) tanggal pembayaran bunga pertama ditetapkan sebelum 6 bulan tanggal penandatangan pinjaman; ketentuan pembayaran tidak dapat diubah setelah Bank menyetujui pinjaman; (7) pinjaman dapat dibayar di muka sebagiannya atau seluruhnya; dan (8) jika pinjaman dibatalkan sebelum tanggal efektif, maka tidak ada biaya front-end yang dikeluarkan (Policy et al., 2017).

Selain menentukan persyaratan pendanaan, Bank juga menentukan persyaratan dalam jaminan yaitu: (1) jaminan dijanjikan dan dibayarkan dalam bentuk Dolar Amerika Serikat, (2) harga jaminan terdiri dari beberapa biaya yang ditentukan berdasarkan kesetaraan pinjaman yang terdiri atas beberapa komponen yang dijelaskan melalui tabel sebagai berikut:

Tabel 4. Komponen jaminan dan biaya jaminan.

\begin{tabular}{|c|c|c|c|}
\hline & Rate & Charged on & $\begin{array}{c}\text { One- } \\
\text { time/recurring }\end{array}$ \\
\hline Front-end Fee & $0.25 \%$ & Guarantee amount & One-time \\
\hline Processing Charge & Up to $0.50 \%$ & Guarantee amount & One-time \\
\hline Standby Fee & $0.25 \%$ & $\begin{array}{l}\text { Undisbursed Amount of } \\
\text { financing benefiting from AIIB } \\
\text { guarantee }\end{array}$ & Recurring \\
\hline Guarantee Fee & $\begin{array}{c}0.50 \%+\text { Maturity } \\
\text { Premium }\end{array}$ & $\begin{array}{l}\text { Financial exposure under the } \\
\text { guarantee (present value of the } \\
\text { guaranteed payments at earliest } \\
\text { call dates) }\end{array}$ & Recurring \\
\hline
\end{tabular}

Sumber: AIIB, Sovereign-Backed Loan and Guarantee Pricing.

(3) Bank dapat membebankan biaya pemrosesan pada proyek spesifik untuk menutupi biaya pemrosesan internal dan eksternal, (4) dewan menetapkan harga jaminan dari waktu ke waktu, (5) biaya jaminan dan biaya siaga dibayarkan di muka, (6) jika selama jaminan eksposur keuangan Bank dikurangi atau dibatalkan maka Bank dapat mengembalikan setengah uang dari biaya jaminan yang telah diterima; (7) perhitungan jatuh tempo ditentukan berdasarkan jenis dan struktur jaminan dan tunduk pada batas akhir rata-rata dan akhir pinjaman, dan (8) pembayaran Bank dengan jaminan tidak dipercepat (Policy et al., 2017).

Bagi anggota yang berada di luar wilayah Asia, AIIB memberikan 
prinsip tambahan yang harus ditaati oleh angggota di luar kawasan untuk memenuhi persyaratan 'significant benefit' bagi Asia yang meliputi empat hal. Pertama, Bank dapat mempertimbangkan investasi dengan tujuan untuk mendukung perdagangan dan konektivitas dengan Asia. Kedua, Bank dapat mempertimbangkan investasi terkait barang publik global seperti proyek pembangkit energi terbarukan. Ketiga, Bank dapat mempertimbangkan anggota nonregional untuk menjadi dewan direksi yang secara geografis dianggap dekat dan secara ekonomi terintegrasi dengan Asia (AIIB, 2018).

\section{Proyek yang Telah Didanai}

Sebelum mengerjakan sebuah proyek, Bank perlu menyetujui pelaksanaan suatu proyek. Tahap pertama adalah strategic programming yang merupakan peninjauan ide dan proposal dari pihak pengusul. Proyek yang telah memenuhi kriteria penyaringan awal akan dimasukkan dalam program investasi bergulir yang akan dibahas dan disetujui oleh Komite Eksekutif. Tahap kedua, adalah project identification, yakni tahap penyerahan dokumen ringkasan proyek dan laporan kelayakan. Setelah itu informasi yang diserahkan akan ditinjau dan kemungkinan Bank akan melakukan penelitian tambahan seperti kunjungan lapangan. Tahap ketiga adalah project preparation, yakni, tim proyek AIIB dan lembaga yang ditunjuk peminjam akan bekerjasama dalam desain proyek dan penilaian tim AIIB yang dilanjutkan dengan persiapan dokumen yang akan diselesaikan setelah peninjauan internal. Tahap keempat adalah board approval, yakni, negosiasi kepada pihak peminjam, dokumen proyek akan diserahkan kepada Dewan AIIB. Namun pinjaman hanya akan efektif jika telah memenuhi efektivitas peminjaman. Tahap kelima adalah project implementation di mana tim AIIB akan terlibat penuh selama masa ini. Tahap keenam adalah project completion and evaluation dimana AIIB akan memberikan laporan penyelesaian proyek kepada Dewan Direksi (AIIB, t.t).

Beberapa proyek yang telah dilaksanakan oleh AIIB akan dijelaskan secara singkat melalui tabel dibawah ini:

Tabel 5. Proyek yang didanai AIIB

\section{Nama Proyek}

Andhra Pradesh Urban Water Supply and Septage Management Improvement Project Mandalika Urban and Tourism Infrastructure Project

$\begin{array}{ccc}\text { Negara } & \begin{array}{c}\text { Jumlah } \\ \text { Pinjaman AIIB }\end{array} & \begin{array}{c}\text { Perkiraan Biaya } \\ \text { Proyek }\end{array} \\ \text { India } & \$ 400 \text { juta } & \$ 517 \text { juta } \\ \text { Indonesia } & \$ 248.8 \text { juta } & \$ 316.5 \text { juta }\end{array}$




\begin{tabular}{|c|c|c|c|}
\hline $\begin{array}{l}\text { TSKB Sustainable Energy and Infrastructure } \\
\text { On-Lending Facility }\end{array}$ & Turkey & $\$ 200$ juta & $\$ 235$ juta \\
\hline Sustainable Rural Sanitation Services Program & Mesir & $\$ 300$ juta & $\$ 694$ juta \\
\hline Andhra Pradesh Rural Roads Project & India & $\$ 455$ juta & $\$ 666$ juta \\
\hline $\begin{array}{l}\text { Strategic Irrigation Modernization and Urgent } \\
\text { Rehabilitation Project }\end{array}$ & Indonesia & $\$ 250$ juta & $\$ 578$ juta \\
\hline Turkey Gas Storage Expansion Project & Turkey & $\$ 600$ juta & $\$ 2,735$ juta \\
\hline $\begin{array}{l}\text { National Investment and Infrastructure Fund } \\
\text { Phase I }\end{array}$ & India & $\$ 100$ juta & $\begin{array}{l}\$ 600 \text { juta (target } \\
\text { pendanaan) }\end{array}$ \\
\hline Madhya Pradesh Rural Connectivity Project & India & $\$ 140$ juta & $\$ 502$ juta \\
\hline Bangladesh Bhola IPP & Bangladesh & $\$ 60$ juta & $\$ 271$ juta \\
\hline $\begin{array}{l}\text { Beijing Air Quality Improvement and Coal } \\
\text { Replacement Project }\end{array}$ & China & $\$ 250$ juta & $\$ 761.10$ juta \\
\hline Oman Broadband Infrastructure Project & Oman & $\$ 239$ juta & $\$ 467$ juta \\
\hline Bangalore Metro Rail Project - Line R6 & India & $\$ 335$ juta & $\$ 1,785$ juta \\
\hline Metro Manila Flood Management Project & Filipina & $\$ 207.60$ juta & $\$ 500$ juta \\
\hline $\begin{array}{l}\text { Transmission System Strengthening Project } \\
\text { (Tamil Nadu) }\end{array}$ & India & $\$ 100$ juta & $\$ 303.47$ juta \\
\hline Gujarat Rural Roads (MMGSY) Project & India & $\begin{array}{c}\text { \$328.18 juta } \\
\text { (Biaya pokok) } \\
\$ 329 \text { juta (front- } \\
\text { end) }\end{array}$ & $\$ 1,5$ miliar \\
\hline $\begin{array}{l}\text { Nurek Hydropower Rehabilitation Project, } \\
\text { Phase I }\end{array}$ & Tajikistan & $\$ 225.70$ juta & $\$ 350$ juta \\
\hline India Infrastructure Fund & India & Up to $\$ 150$ juta & $\begin{array}{l}\$ 750 \text { juta (target } \\
\text { pendanaan) }\end{array}$ \\
\hline $\begin{array}{l}\text { Trans Anatolian Natural Gas Pipeline Project } \\
\text { (TANAP) To be co-financed with the World } \\
\text { Bank (WB) }\end{array}$ & Azerbaijan & $\$ 600$ juta & $\$ 8,6$ miliar \\
\hline $\begin{array}{l}\text { Myingyan } 225 \text { MW Combined Cycle Gas } \\
\text { Turbine (CCGT) Power Plant Project, } \\
\text { Myanmar }\end{array}$ & Myanmar & $\$ 20$ juta & \\
\hline Tarbela 5 Hydropower Extension Project & Pakistan & $\$ 300$ juta & $\$ 823.5$ juta \\
\hline $\begin{array}{l}\text { Dushanbe-Uzbekistan Border Road } \\
\text { Improvement Project (Cofinanced with the } \\
\text { European Bank for Reconstruction and } \\
\text { Development) }\end{array}$ & Tajikistan & & $\$ 105.9$ juta \\
\hline
\end{tabular}

Sumber: www.aiib.org

Tabel tersebut berisi beberapa proyek yang didanai oleh AIIB. Dari tabel tersebut terlihat bahwa AIIB telah mendanai banyak proyek terutama di proyek di regionalnya. Namun dalam mendanai proyek tersebut AIIB tidak serta merta memberikan pinjaman sebesar total perkiraan dana yang dibutuhkan oleh proyek tersebut. Seperti dalam Strategic Irrigation
Modernization and Urgent Rehabilitation Project di Indonesia, AIIB hanya memberikan pinjaman sebesar $\$ 250$ juta dari jumlah perkiraan dana sebesar $\$ 578$ juta yang berarti dana tersebut hanya berjumlah 43,25\% dari jumlah dana yang dibutuhkan. Hal yang sama juga terdapat pada proyek di Azerbaijan yang bernama Trans Anatolian Natural Gas Pipeline Project 
(TANAP) To be co-financed with the World Bank mendanai sebesar $\$ 600$ juta dari jumlah perkiraan biaya sebesar $\$ 8,6$ miliar yang berarti hanya sebesar 6,98\% dari jumlah biaya. Kekurangan dana tersebut didanai oleh World Bank sebesar $\$ 800$ juta, EBRD dan EIB sebesar \$2,100 juta dan dana terbesar diberikan oleh peminjaman komersial lain yang berjumlah $\$ 3,000$ juta.

\section{Respon terhadap AIIB}

Kemunculan AIIB sebagai MDB baru di Asia menimbulkan banyak respon dari negara-negara lain. Beberapa ilmuwan menganggap pembentukan AIIB adalah respon Tiongkok terhadap Amerika Serikat (Callaghan \& Hubbard, 2016). Pembangunan jalur sutra baru yang direncanakan ditujukan untuk ekspansi pasar ekspor Tiongkok. Amerika Serikat mencurigai kemunculan MDB baru ini karena dipandang sebagai upaya menyaingi MDB lainnya seperti rezim Bretton-Woods (Callaghan \& Hubbard, 2016).

Respon lain dari Amerika Serikat atas munculnya MDB ini adalah mengajak sekutu-sekutunya untuk tidak bergabung dalam keanggotaan AIIB. Namun, satu persatu sekutunya justru bergabung dengan AIIB dengan pengecualian Jepang. Pada isi lain, AIIB justru mendapatkan respon yang sangat positif dari negara-negara Asia.
Mereka menganggap sistem birokratik yang ada di AIIB lebih mudah dari pada MDB utama seperti IMF dan World Bank. Selain itu, bunga pinjaman AIIB lebih rendah dari MDB lainnya. Alasan tersebutlah yang mendorong negara-negara dunia ketiga untuk bergabung dengan AIIB.

\section{Ketergantungan Negara Dunia Ketiga Terhadap Aiib}

Beberapa alasan bergabungnya negara dunia ketiga ke dalam AIIB banyak didorong oleh efisinsi birokrasi dan keringanan bunga yang ditawarkan oleh AIIB. Namun, hal ini membuat negara-negara dunia ketiga terus menerus menggunakan uang pinjaman dari AIIB untuk membangun infrastruktur di negaranya. Kecenderungan seperti itu, membuat negara-negara dunia ketiga terus bergantung pada AIIB. Tiongkok sebagai pendiri dan pencetus AIIB akan menggunakan hal tersebut untuk lebih memperluas pengaruhnya kepada dunia ketiga.

\section{Kondisi} demikian mengilustrasikan tentang adanya ketergantungan negara sebagaimana yang dimaksud dalam teori depedensi. Seperti halnya yang dilakukan oleh India (lihat tabel 5), kecilnya bunga pinjaman AIIB membuat India terus melakukan peminjaman dana dari AIIB. Terlihat jelas pada tabel 5 bahwa 
India adalah negara yang paling banyak memanfaatkan pinjaman dana untuk menjalankan proyek pembangunan dalam negeri. Pada sisi lainnya, hal tersebut justru sangat menguntungkan Tiongkok sebagai negara pencetus AIIB untuk memperluas jangkauan pengaruhnya di dunia terutama di Asia.

\section{Tiongkok Sebagai Leader}

Kebijakan Tiongkok dalam satu dekade terakhir dianggap sebagai langkah untuk menjadi pemimpin di wilayah Asia Timur (Raharyo, 2013). Terdapat tiga alasan mengapa pendirian AIIB merupakan usaha untuk meningkatkan kepemimpinan Tiongkok di Asia Timur. Pertama, pendirian AIIB oleh Tiongkok dianggap sebagai penyediaan ruang publik untuk wilayah Asia Timur yang merupakan salah satu elemen kunci yang membentuk regionalisme. Kedua, Tiongkok berusaha menjadi pemimpin kawasan sejak membuka hubungan multilateral dengan ASEAN. Ketiga, tata kelola dan keanggotaan AIIB yang membuat negara-negara di Asia memiliki lebih banyak ruang untuk berkontribusi lebih baik dalam rezim keuangan internasional, hal tersebut merupakan langkah untuk menunjukkan dan menarik wilayah Asia untuk menjadikan Tiongkok sebagai pemimpin (Raharyo, 2013).
Kehadiran AIIB sebagai MDB baru dapat menghadirkan fitur yang lebih baik dari pada ADB. Keuntungan-keuntungan yang tidak didapatkan pada MDB lain diberikan oleh AIIB, hal tersebut menjadi daya tarik tersendiri untuk AIIB. Banyaknya negara-negara yang bergabung dengan AIIB terutama wilayah Asia Timur membuat Tiongkok dapat mengejar ketertinggalannya dari Jepang. Pembentukan AIIB sebagai kerjasama multilateral Tiongkok setidaknya menggambarkan kebijakan yang mendukung kepemimpinan di kawasan.

\section{Hegemoni Baru Tiongkok}

Kemudahan-kemudahan yang ditawarkan oleh AIIB membuat banyak negara dunia ketiga untuk terus memanfaatkan dana AIIB untuk kebutuhan pembangunan infrastruktur negaranya. Hal tersebutlah yang akan membuat negara-negara di Asia menjadi tergantung pada Tiongkok selaku pendiri AIIB. Ketergantungan tersebut secara tidak langsung dapat memunculkan hegomoni dan perwujudan kepemimpinan Tiongkok terhadap negara-negara Asia di kawasan. Kedua alasan tersebut cukup untuk menjadikan Tiongkok sebagai negara hegemonik di kawasan Asia. 


\section{KESIMPULAN}

Kehadiran AIIB sebagai MDB baru yang diinisiasikan oleh Tiongkok dengan jumlah anggota yang telah mencapai 93 negara menjadikannya sebagai MDB yang cukup berhasil di regionalnya. Pendirian AIIB ini memberikan kemudahan-kemudahan kepada negara anggotanya yang tidak dapat ditemui di MDB lain. Kemudahan tersebut berupa birokrasi atau sistem peminjaman yang lebih mudah dan dana yang lebih cepat cair, serta bunga peminjaman yang lebih rendah dibandingkan negara lain. AIIB memiliki modal awal senilai $\$ 100.000 .000 .000$, walaupun modal ini sangat kurang dibandingkan kebutuhan pembangunan di negara anggota, AIIB tetap dapat memenuhi kebutuhan tersebut dengan bekerjasama dengan MDB lain.

Kemudahan yang diberikan AIIB membuat negara anggotanya menjadi lebih tergantung dengan MDB ini dan Tiongkok sebagai pendirinya. Selain itu, keinginan dan usaha Tiongkok untuk menjadi pemimpin kawasan menjadikan AIIB sebagai alat untuk mencapai keinginannya tersebut. Alasan tersebut dapat diambil kesimpulan bahwa Tiongkok menjadikan AIIB sebagai alat pemenuhan kepentingan dan alat untuk mencapai hegemoni di kawasan.

\section{DAFTAR PUSTAKA}

Åberg, J. H. S. (2016) 'A Struggle for Leadership Recognition: The AIIB, Reactive Chinese Assertiveness, and Regional Order'. Contemporary Chinese Political Economy and Strategic Relations: An International Journal, 2(3), pp. 11251171.

ADB. (2017) Asia Infrastructure Needs Exceed $\$ 1.7$ Trillion Per Year, Double Previous Estimates [online]. Available at: https://www.adb.org/news/asiainfrastructure-needs-exceed-17trillion-year-double-previous-estimates (Diakses: 11 Maret 2019).

AIIB. (t.t) Our Story So Far [online]. Available at: https://www.aiib.org/en/aboutaiib/who-we-are/timeline/index.html (Diakses: 11 Maret 2019).

AIIB. (t.t) Who We Are. Available at: https://www.aiib.org/en/aboutaiib/index.html (Diakses 9 Maret 2019).

AIIB. (t.t) Financing Operations [online]. Available at: https://www.aiib.org/en/aboutaiib/who-we-are/financingoperations/index.html (Diakses: 13 Maret 2019).

AIIB. (t.t) Project Process [online]. Available at: https://www.aiib.org/en/projects/pr ocess/index.html (Diakses: 14 Maret 2019).

AIIB. (2016) Asian Infrastructure Investment Bank, Articles of Agreement [online] Available at: http://www.aiibank.org/uploadfile/2 015/0814/20150814022158430.pdf (Diakses: 14 Maret 2019).

AIIB. (2018) Strategy On Financing Operations in Non-Regional Member, Article of Agreement 1, pp.1-2 [online]. Available at: https://www.aiib.org/en/policiesstrategies/strategies/financing- 
operations.html 1, (Diakses: 14 Maret 2019).

Bob, D., Kawai, M., Sun, Y., \& Harris, T. (2015) Asian Infrastructure Investment Bank: China as Responsible Stakeholder? [online]. Available at: https://spfusa.org/wpcontent/uploads/2015/07/AIIBReport_4web.pdf (Diakses: 13 Maret 2019).

Callaghan, M., \& Hubbard, P. (2016) The Asian Infrastructure Investment Bank: Multilateralism on the Silk Road The Asian Infrastructure Investment Bank: Multilateralism on the Silk Road [online]. Available at: https://doi.org/10.1080/17538963.20 16.1162970 (Diakses: 14 Maret 2019).

Chow, D. C. K. (2016) 'Why China Established the Asia Infrastructure Investment Bank', V anderbilt Journal of Transnational Law, Vol. 49, No. 333.

Debora, Y. (2017) AIIB, Penantang Baru Bank Dunia dan IMF dari Cina [online]. Available at: https://tirto.id/aiibpenantang-baru-bank-dunia-dan-imfdari-cina-cCcj (Diakses: 14 Maret 2019).

Ferraro, V. (1996) 'Dependency Theory: An Introduction'. The Development Economics Reader [online]. Available at: http://marriottschool.net/emp/WP W/pdf/class/Class_6-

The_Dependency_Perspective.pdf (Diakses: 17 Maret 2019).

Insani, Nur \& Mardhiyah, Ranni Sitti. (2017) Prospek Implementasi Asian Infrastructure Investment Bank (Aiib) Terbadap Peningkatan Kerjasama Ekonomi Tiongkok Di Asia Tenggara (Studi Kasus : AIIB di Indonesia Dan Myanmar) [online]. Skripsi. Makassar: S1 Hubungan Internasional Universitas Hasanuddin.
Mas'oed, M. (1990) Ilmu Hubungan Internasional: Disiplin dan Metodologi (cetakan pertama). Jakarta: LP3ES.

Policy, O., Financing, N., Policy, T., I-vi, S., Provisions, S., Financing, S., ... Agreements, L. (2017). 'Operational Policy on Financing, Jannuary 2016, pp. 1-27.

Raharyo, A. (2013) 'Asian Infrastructure Investment Bank ( AIIB ) as an Instrument for Regional Leadership of China in the East Asia Region' [online] 2(2), pp. 109-124. Available at: http://ejournal.president.ac.id/presunivojs/in dex.php/AEGIS/article/view/422/2 57 (Diakses: 12 Maret 2019).

Ramo, J. C. (2004) The Beijing Consensus. London: Foreign Policy Centre.

Samuel. (2016) Metode Pengumpulan Data Dalam Penelitian [online]. Available at: http://ciputrauceo.net/blog/2016/2/ 18/metode-pengumpulan-data-dalampenelitian (Diakses 17 Maret 2019).

Silfiana, D. (2018) Pembangunan Ekonomi Cina Berdasarkan Teori Deng Xiaoping Dan Konsep Tiga Perwakilan [online]. Available at: ejournal.hi.fisipunmul.ac.id/site/wpcontent/uploads/2018/07/12020450 41\%20- $\% 20$ Dara $\% 20$ Silfiana $\% 20(07-$ 18-18-07-23-41).pdf (Diakses: 17 Maret 2019).

Wahidmurni, M. P. (2017) Pemaparan Metode Penelitian Kualitatif. Available at: repository.uinmalang.ac.id/1985/2/1985.pdf (Diakses 14 Maret 2019).

Weiss, M. A. (2017) Asian Infrastructure Investment Bank (AIIB) [online]. Available at: https://digital.library.unt.edu/ark:/67 531/metadc958727/m1/1/ (Diakses: 17 Maret 2019). 